(C) 2015

Міленко О. Г., асистент

(науковий керівник - доктор сільськогосподарських наук, профессор М. Я. Шевніков)

Полтавська державна аграрна академія

\title{
ЗМІНА ТРИВАЛОСТІ ПЕРІОДУ ВЕГЕТАЦІЇ ТА ФАЗ РОСТУ І РОЗВИТКУ РОСЛИН СОЇ ЗАЛЕЖНО ВІД УМОВ ВИРОЩУВАННЯ
}

\section{Рецензент - доктор сільськогосподарських наук В. М. Тищенко}

Висвітлено вплив погодних умов, властивостей сортів, різних способів догляду за посівами та норм висіву насіння на тривалість вететаційного періоду і проходження фаз росту та розвитку рослин сої. Найбільше на тривалість періоду вететації та окремих фаз росту і розвитку рослин сої впливали погодні умови року. Спостерігалось значне скорочення вететачійного періоду рослин сої в посушливі роки. Спосіб догляду за посівами неістотно впливав на органогенез рослин сої. Загущеність агрофітоценозу позначилось на проходженні фаз росту і розвитку сортів Романтика та Устя. Підвищенні норми висіву сприяли скороченню періодів формування бобів та наливання насіння.

Ключові слова: соя, сорт, норма висіву, вететаційний період, фази росту і розвитку.

Постановка проблеми. Соя, як культурна рослина, залежно від сорту, має свої особливості щодо форми стебла, висоти рослин, кількості гілочок і листків, квіток і суцвіть, формування бобів і насіння. Залежно від тривалості вегетаційного періоду та окремих його фаз змінюється зернова продуктивність сортів сої. Тому, важливим питанням дослідної роботи в рослинництві є вивчення основних фаз росту і розвитку культури, встановлення тривалості ії вегетаційного періоду [2].

Аналіз основних досліджень і публікацій, у яких започатковано розв'язання проблеми. За багатовікову історію селекції і вирощування сої, вона увібрала найцінніші властивості рослинного світу: відзначається пластичністю, чутливістю до грунтово-кліматичних умов, високим потенціалом продуктивності, різною холодостійкістю, посухостійкістю, вологоспоживанням, строками достигання [1]. Метеорологічні умови та агротехнічні заходи впливають не лише на загальну тривалість вегетаційного періоду, а й на довжину окремих фаз росту і розвитку в онтогенезі сої $[3,4]$.

Метою наших досліджень було проаналізувати тривалість вегетаційного періоду та фаз росту і розвитку рослин сої сортів Романтика та Устя, залежно від норм висіву та способів догляду за посівами.
Завдання досліджень - провести фенологічні спостереження за ростом та розвитком рослин сої сортів Романтика і Устя залежно від умов вирощування.

Матеріали і методи досліджень. Польові дослідження проводились протягом 2007-2009 років на дослідному полі навчально-дослідного господарства «Ювілейний» Полтавської державної аграрної академії. Технологія вирощування сої була загальноприйнятою для даної зони, відрізнялась по варіантах, в залежності від факторів, які вивчались у досліді. Оскільки на тривалість періоду вегетації рослин істотно впливають погодні умови року, результати досліджень бажано наводити за кожен рік окремо.

Результати досліджень. В таблицях 1, 2 та 3 наведено дані про тривалість вегетації та міжфазних періодів росту та розвитку рослин сої залежно від сорту, норм висіву та способів догляду за посівами. Тривалість періоду «сівба - сходи» за варіантами досліду не відрізнялась, але суттєво залежала від погодних умов. У 2008 і 2009 роках була на 4 і 2 доби довшою по відношенню до 2007 року. Це пояснюється недостатньою кількістю атмосферних опадів на час сівби культури.

Появу першої пари трійчастих листків у рослин сої після масових сходів ми спостерігали протягом 10 днів у сорту Устя та протягом 11 днів у сорту Романтика. Погодні умови за роки досліджень на тривалість періоду «сходи - перша пара трійчастих листків» не впливали.

Фаза галуження характеризувалась інтенсивним ростом вегетативної маси та розростанням кореневої системи, формувалось стебло та бокові гілки. В засушливий 2008 рік по сорту Устя період «перша пара трійчастих листків - галуження» тривав на 2 дні менше, а по сорту Романтика на 1 день був коротшим. Потрібно зазначити, що зі збільшенням норм висіву по варіантах на більшості рослинах взагалі не утворювались бічні гілочки, тобто галуження рослин не відбувалося, а проходження цієї фази характеризувалось тільки інтенсивним ростом та розвитком одного стебла. 


\section{СТОРІНКА МОЛОДОГО ВЧЕНОГО}

1. Тривалість вететації та міжсфазних періодів росту та розвитку рослин сої залежсно від сорту, способів догляду за культурою та норм висіву насіння, діб (2007 р.)

\begin{tabular}{|c|c|c|c|c|c|c|c|c|c|c|c|}
\hline \multirow[b]{2}{*}{$\stackrel{\overrightarrow{0}}{0}$} & \multirow[b]{2}{*}{$\begin{array}{c}\text { Спосіб догляду } \\
\text { за культурою }\end{array}$} & \multirow[b]{2}{*}{ 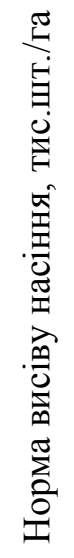 } & \multicolumn{8}{|c|}{ Тривалість міжфазних періодів росту та розвитку } & \multirow[b]{2}{*}{ 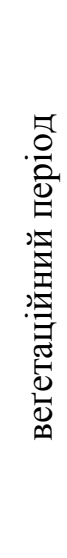 } \\
\hline & & & \begin{tabular}{l}
\multirow{1}{*}{} \\
0 \\
0 \\
0 \\
1 \\
$\tilde{0}$ \\
0 \\
.0 \\
0
\end{tabular} & 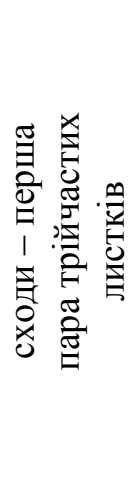 & 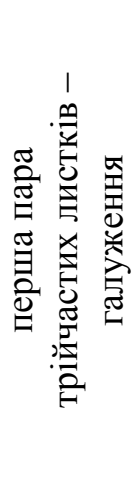 & 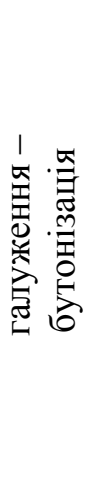 & 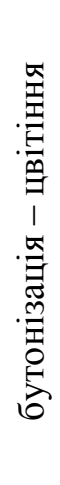 & 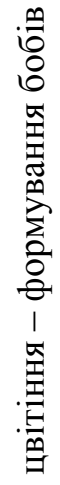 & 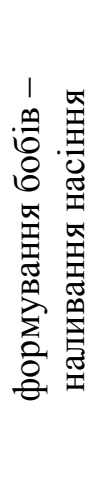 & 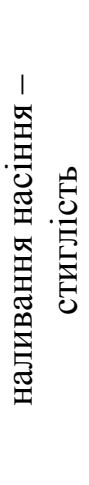 & \\
\hline \multirow{12}{*}{ 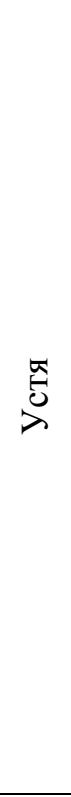 } & \multirow{4}{*}{ Без догляду } & 600 & 8 & 10 & 12 & 13 & 16 & 18 & 18 & 19 & 106 \\
\hline & & 700 & 8 & 10 & 12 & 13 & 16 & 18 & 18 & 19 & 106 \\
\hline & & 800 & 8 & 10 & 12 & 13 & 16 & 18 & 18 & 17 & 104 \\
\hline & & 900 & 8 & 10 & 12 & 13 & 16 & 18 & 17 & 17 & 103 \\
\hline & \multirow{4}{*}{$\begin{array}{c}\text { Механічний } \\
\text { догляд }\end{array}$} & 600 & 8 & 10 & 12 & 13 & 16 & 18 & 18 & 17 & 104 \\
\hline & & 700 & 8 & 10 & 12 & 13 & 16 & 18 & 17 & 17 & 103 \\
\hline & & 800 & 8 & 10 & 12 & 13 & 16 & 17 & 17 & 17 & 102 \\
\hline & & 900 & 8 & 10 & 12 & 13 & 16 & 17 & 17 & 17 & 102 \\
\hline & \multirow{4}{*}{$\begin{array}{l}\text { Хімічний } \\
\text { догляд }\end{array}$} & 600 & 8 & 10 & 12 & 13 & 16 & 17 & 18 & 17 & 103 \\
\hline & & 700 & 8 & 10 & 12 & 13 & 16 & 17 & 18 & 16 & 102 \\
\hline & & 800 & 8 & 10 & 12 & 13 & 16 & 17 & 17 & 16 & 101 \\
\hline & & 900 & 8 & 10 & 12 & 13 & 16 & 17 & 17 & 15 & 100 \\
\hline \multirow{12}{*}{ 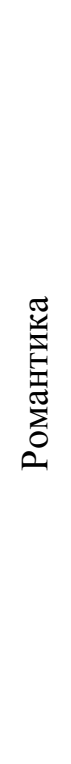 } & \multirow{4}{*}{ Без догляду } & 600 & 8 & 11 & 13 & 15 & 17 & 18 & 18 & 24 & 116 \\
\hline & & 700 & 8 & 11 & 13 & 15 & 17 & 18 & 18 & 22 & 114 \\
\hline & & 800 & 8 & 11 & 13 & 15 & 17 & 18 & 17 & 22 & 113 \\
\hline & & 900 & 8 & 11 & 13 & 15 & 17 & 17 & 16 & 22 & 111 \\
\hline & \multirow{4}{*}{$\begin{array}{c}\text { Механічний } \\
\text { догляд }\end{array}$} & 600 & 8 & 11 & 13 & 15 & 17 & 19 & 18 & 20 & 113 \\
\hline & & 700 & 8 & 11 & 13 & 15 & 17 & 19 & 18 & 20 & 113 \\
\hline & & 800 & 8 & 11 & 13 & 15 & 17 & 19 & 17 & 20 & 112 \\
\hline & & 900 & 8 & 11 & 13 & 15 & 17 & 19 & 17 & 19 & 111 \\
\hline & \multirow{4}{*}{$\begin{array}{l}\text { Хімічний } \\
\text { догляд }\end{array}$} & 600 & 8 & 11 & 13 & 15 & 17 & 19 & 18 & 20 & 113 \\
\hline & & 700 & 8 & 11 & 13 & 15 & 17 & 19 & 18 & 19 & 112 \\
\hline & & 800 & 8 & 11 & 13 & 15 & 17 & 18 & 17 & 18 & 109 \\
\hline & & 900 & 8 & 11 & 13 & 15 & 17 & 18 & 17 & 17 & 108 \\
\hline
\end{tabular}


2. Тривалість вететації та міжффазних періодів росту та розвитку рослин сої залежсно від сорту, способів догляду за культурою та норм висіву насіння, діб (2008 р.)

\begin{tabular}{|c|c|c|c|c|c|c|c|c|c|c|c|}
\hline \multirow[b]{2}{*}{ ò } & \multirow[b]{2}{*}{$\begin{array}{c}\text { Спосіб догляду } \\
\text { за культурою }\end{array}$} & \multirow[b]{2}{*}{ 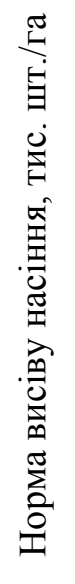 } & \multicolumn{8}{|c|}{ Тривалість міжфазних періодів росту та розвитку } & \multirow[b]{2}{*}{ 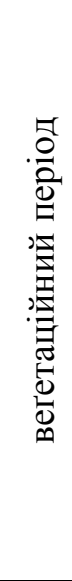 } \\
\hline & & & 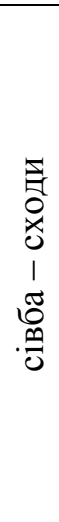 & 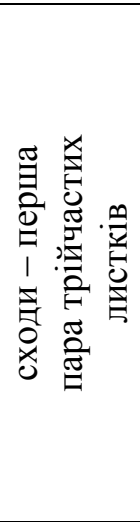 & 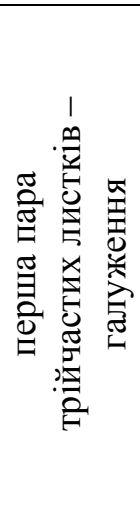 & 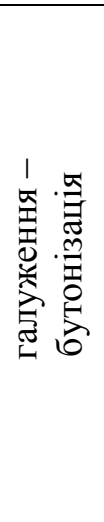 & 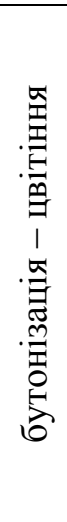 & 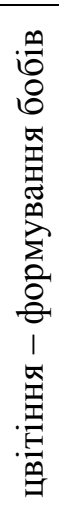 & 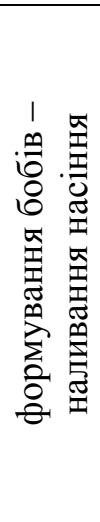 & 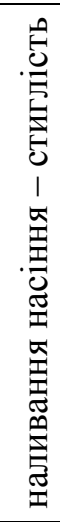 & \\
\hline \multirow{12}{*}{$\stackrel{\substack{5 \\
\nu}}{\lambda}$} & \multirow{4}{*}{ Без догляду } & 600 & 12 & 10 & 10 & 12 & 16 & 16 & 18 & 17 & 99 \\
\hline & & 700 & 12 & 10 & 10 & 12 & 16 & 16 & 18 & 17 & 99 \\
\hline & & 800 & 12 & 10 & 10 & 12 & 16 & 16 & 18 & 17 & 99 \\
\hline & & 900 & 12 & 10 & 10 & 12 & 16 & 16 & 17 & 17 & 98 \\
\hline & \multirow{4}{*}{$\begin{array}{c}\text { Механічний } \\
\text { догляд }\end{array}$} & 600 & 12 & 10 & 10 & 12 & 16 & 16 & 18 & 17 & 99 \\
\hline & & 700 & 12 & 10 & 10 & 12 & 16 & 16 & 18 & 17 & 99 \\
\hline & & 800 & 12 & 10 & 10 & 12 & 16 & 16 & 18 & 16 & 98 \\
\hline & & 900 & 12 & 10 & 10 & 12 & 16 & 16 & 17 & 16 & 97 \\
\hline & \multirow{4}{*}{$\begin{array}{l}\text { Хімічний } \\
\text { догляд }\end{array}$} & 600 & 12 & 10 & 10 & 12 & 16 & 16 & 16 & 17 & 97 \\
\hline & & 700 & 12 & 10 & 10 & 12 & 16 & 16 & 16 & 17 & 97 \\
\hline & & 800 & 12 & 10 & 10 & 12 & 16 & 16 & 15 & 16 & 95 \\
\hline & & 900 & 12 & 10 & 10 & 12 & 16 & 16 & 15 & 15 & 94 \\
\hline \multirow{12}{*}{ 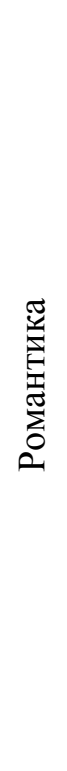 } & \multirow{4}{*}{ Без догляду } & 600 & 11 & 11 & 12 & 14 & 17 & 18 & 18 & 20 & 110 \\
\hline & & 700 & 11 & 11 & 12 & 14 & 17 & 18 & 18 & 20 & 110 \\
\hline & & 800 & 11 & 11 & 12 & 14 & 17 & 17 & 17 & 19 & 107 \\
\hline & & 900 & 11 & 11 & 12 & 14 & 17 & 17 & 17 & 19 & 107 \\
\hline & \multirow{4}{*}{$\begin{array}{c}\text { Механічний } \\
\text { догляд }\end{array}$} & 600 & 11 & 11 & 12 & 14 & 17 & 18 & 18 & 19 & 109 \\
\hline & & 700 & 11 & 11 & 12 & 14 & 17 & 18 & 18 & 19 & 109 \\
\hline & & 800 & 11 & 11 & 12 & 14 & 17 & 17 & 18 & 19 & 108 \\
\hline & & 900 & 11 & 11 & 12 & 14 & 17 & 17 & 17 & 19 & 107 \\
\hline & \multirow{4}{*}{$\begin{array}{l}\text { Хімічний } \\
\text { догляд }\end{array}$} & 600 & 11 & 11 & 12 & 14 & 17 & 18 & 18 & 20 & 110 \\
\hline & & 700 & 11 & 11 & 12 & 14 & 17 & 18 & 17 & 19 & 108 \\
\hline & & 800 & 11 & 11 & 12 & 14 & 17 & 17 & 16 & 19 & 106 \\
\hline & & 900 & 11 & 11 & 12 & 14 & 17 & 17 & 16 & 18 & 105 \\
\hline
\end{tabular}


3. Тривалість вететації та міжфазних періодів росту та розвитку рослин сої залежно від сорту, способів догляду за культурою та норм висіву насіння, діб (2009 р.)

\begin{tabular}{|c|c|c|c|c|c|c|c|c|c|c|c|}
\hline \multirow[b]{2}{*}{$\tilde{o}^{2}$} & \multirow[b]{2}{*}{$\begin{array}{c}\text { Спосіб } \\
\text { догляду за } \\
\text { культурою }\end{array}$} & \multirow[b]{2}{*}{ 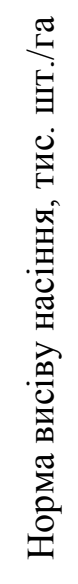 } & \multicolumn{8}{|c|}{ Тривалість міжфазних періодів росту та розвитку } & \multirow[b]{2}{*}{ 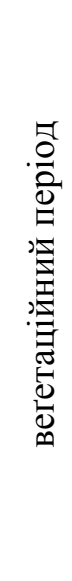 } \\
\hline & & & 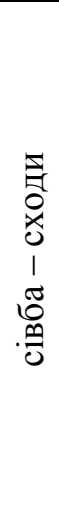 & 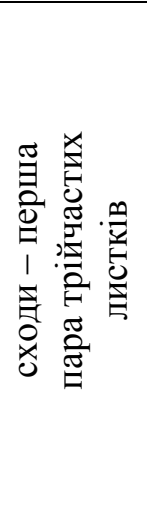 & 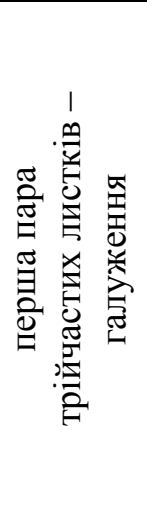 & 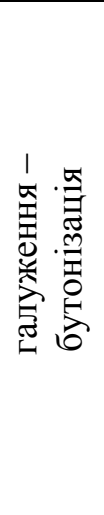 & 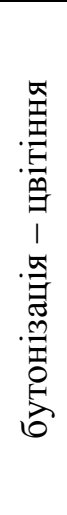 & 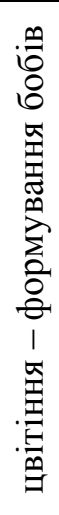 & 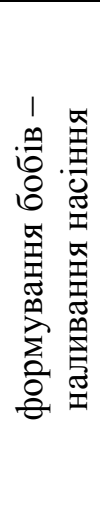 & 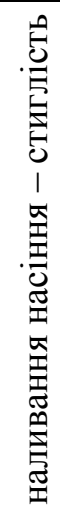 & \\
\hline \multirow{12}{*}{ 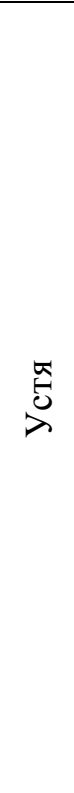 } & \multirow{4}{*}{ Без догляду } & 600 & 10 & 10 & 12 & 13 & 16 & 17 & 18 & 18 & 104 \\
\hline & & 700 & 10 & 10 & 12 & 13 & 16 & 17 & 18 & 18 & 104 \\
\hline & & 800 & 10 & 10 & 12 & 13 & 16 & 17 & 18 & 17 & 103 \\
\hline & & 900 & 10 & 10 & 12 & 13 & 16 & 17 & 17 & 17 & 102 \\
\hline & \multirow{4}{*}{$\begin{array}{c}\text { Механічний } \\
\text { догляд }\end{array}$} & 600 & 10 & 10 & 12 & 13 & 16 & 17 & 18 & 17 & 103 \\
\hline & & 700 & 10 & 10 & 12 & 13 & 16 & 17 & 18 & 17 & 103 \\
\hline & & 800 & 10 & 10 & 12 & 13 & 16 & 17 & 17 & 17 & 102 \\
\hline & & 900 & 10 & 10 & 12 & 13 & 16 & 17 & 17 & 17 & 102 \\
\hline & \multirow{4}{*}{$\begin{array}{l}\text { Хімічний } \\
\text { догляд }\end{array}$} & 600 & 10 & 10 & 12 & 13 & 16 & 17 & 17 & 17 & 102 \\
\hline & & 700 & 10 & 10 & 12 & 13 & 16 & 17 & 17 & 16 & 101 \\
\hline & & 800 & 10 & 10 & 12 & 13 & 16 & 17 & 16 & 16 & 100 \\
\hline & & 900 & 10 & 10 & 12 & 13 & 16 & 16 & 16 & 16 & 99 \\
\hline \multirow{12}{*}{ 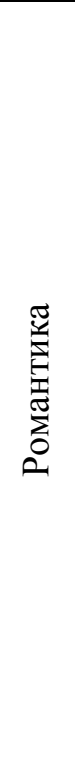 } & \multirow{4}{*}{ Без догляду } & 600 & 10 & 11 & 13 & 15 & 17 & 20 & 18 & 20 & 114 \\
\hline & & 700 & 10 & 11 & 13 & 15 & 17 & 19 & 18 & 20 & 113 \\
\hline & & 800 & 10 & 11 & 13 & 15 & 17 & 19 & 18 & 20 & 113 \\
\hline & & 900 & 10 & 11 & 13 & 15 & 17 & 18 & 18 & 20 & 112 \\
\hline & \multirow{4}{*}{$\begin{array}{l}\text { Механічний } \\
\text { догляд }\end{array}$} & 600 & 10 & 11 & 13 & 15 & 17 & 19 & 18 & 19 & 112 \\
\hline & & 700 & 10 & 11 & 13 & 15 & 17 & 19 & 18 & 19 & 112 \\
\hline & & 800 & 10 & 11 & 13 & 15 & 17 & 18 & 18 & 19 & 111 \\
\hline & & 900 & 10 & 11 & 13 & 15 & 17 & 18 & 17 & 19 & 110 \\
\hline & \multirow{4}{*}{$\begin{array}{c}\text { Хімічний } \\
\text { догляд }\end{array}$} & 600 & 10 & 11 & 13 & 15 & 17 & 18 & 18 & 19 & 111 \\
\hline & & 700 & 10 & 11 & 13 & 15 & 17 & 18 & 18 & 19 & 111 \\
\hline & & 800 & 10 & 11 & 13 & 15 & 17 & 18 & 16 & 18 & 108 \\
\hline & & 900 & 10 & 11 & 13 & 15 & 17 & 17 & 16 & 18 & 107 \\
\hline
\end{tabular}

Під час фази бутонізації інтенсивно росло стебло у висоту, на деяких рослинах частково відбувалося галуження, формувалися квіткові бруньки та проходила диференціація елементів 


\section{СТОРІНКА МОЛОДОГО ВЧЕНОГО}

квітки. Тривалість періоду «галуження - бутонізація» залежала від сортових особливостей та зволоженості грунту. В сорту Устя цей період був коротшим на 2 дні, ніж у сорту Романтика. Та в більш сприятливі 2007 і 2009 роки по кожному сорту на 1 день цей період був триваліший. Норма висіву та спосіб догляду за посівами суттєво не впливали на проходження розвитку рослин в цей міжфазний період.

Першими зацвітали рослини сорту Устя, інтенсивне цвітіння ми спостерігали в перші 10 днів, котре в наступні 6 днів мало поодинокий характер. В рослин сорту Романтика було відмічено цвітіння більш рівномірне протягом усього періоду. Погодні умови істотно не впливали на тривалість періоду «бутонізація - цвітіння». За допомогою візуальних спостережень було відмічено, що зі збільшенням густоти стояння рослин в посівах сої, суцвіття розміщувались у вищих частинах стебла і галужень. Та на варіантах досліду 3 природною забур'яненістю, як правило, суцвіття в пазухах листків формувались у верхніх ярусах стебла.

Під час фенологічних спостережень дуже важко зафіксувати кінець фази цвітіння та початок фази формування бобів, оскільки у рослин сої вони заходять одна за одну, одночасно відцвітали квіти у верхніх ярусах рослин та були вже розвинуті боби в нижніх ярусах рослин. Тому умовно початок фази формування бобів ми відмічали під час появи в'ялих квіток на верхніх міжвузлях стебла.

В 2007 році тривалість періоду «цвітіння формування бобів» у рослин сорту Устя спостерігалась протягом 18 днів на варіантах досліду 3 природною забур'яненістю та під час механічного способу догляду за посівами з нормами висіву 600 і 700 тис./га. Тривалість цього періоду скоротилась на 1 день за умови збільшення норми висіву до 800 і 900 тис./га під час механічного способу догляду за посівами та на варіантах досліду 3 хімічним способом догляду за посівами незалежно від густоти стояння рослин.

Рослини сорту Романтика в 2007 році формували боби на ділянках досліду без догляду протягом 18 днів, тільки за збільшення норми висіву до 900 тис./га цей період скоротився на 1 день. Протягом 19 днів тривав період «цвітіння - формування бобів» на варіантах досліду 3 механічним способом догляду за посівами не залежно від норми висіву та на варіантах із хімічним способом догляду за норми висіву 600 і 700 тис./га, а під час збільшення норми висіву до 800 і 900 тис./га тривалість цього періоду скоротилась на 1 день.

У 2008 році період «цвітіння - формування бобів» тривав 16 днів у рослин сорту Устя на всіх варіантах досліду незалежно від способів догляду за посівами та норм висіву насіння.

У рослин сорту Романтика 18 днів тривав період «цвітіння - формування бобів» в 2008 році за норми висіву насіння 600 і 700 тис./га незалежно від догляду за посівами, а скорочення тривалості цього періоду на 1 день ми спостерігали під час збільшення норми висіву насіння до 800 i 900 тис./га.

У 2009 році рослини сорту Устя формували боби протягом 17 днів, тільки на варіанті з нормою висіву 900 тис./га за хімічного способу догляду цей період скоротився на 1 день.

Найдовшу тривалість періоду «цвітіння - формування бобів» у рослин сорту Романтика за 2009 рік ми спостерігали на варіанті без догляду 3 нормою висіву насіння 600 тис./га, зі збільшенням норми висіву насіння до 700 і 800 тис./га цей період скоротився на 1 день, а за збільшення до 900 тис./га - ще скоротився на 1 день. На варіантах досліду, де проводився механічний спосіб догляду за посівами період «цвітіння - формування бобів» тривав 19 днів за норми висіву насіння 600 і 700 тис./га, а під час збільшення норми висіву до 800 і 900 тис./га цей період скоротився до 18 днів. Також 18 днів тривав цей період на варіантах досліду із хімічним способом догляду за посівами, тільки за збільшення норми висіву до 900 тис./га тривалість періоду скоротилась до 17 днів.

Міжфазний період росту та розвитку рослин сої «формування бобів - наливання насіння» в 2007 році тривав 18 днів у рослин сорту Устя на варіантах без догляду, скоротився цей період на 1 день зі збільшенням норми висіву насіння до 900 тис./га. На варіантах досліду 3 механічним способом догляду за посівами тривалість періоду до 17 днів скоротилась вже за норми висіву насіння 700 тис./га. Тривалість цього періоду під час хімічного способу догляду за посівами скоротилась на 1 день за збільшення норми висіву насіння до 800 тис./га.

Наливання насіння у рослин сорту Романтика в 2007 році ми спостерігали протягом 18 днів за норми висіву 600 і 700 тис./га незалежно від догляду за посівами та 17 днів під час збільшення норми висіву насіння до 800 і 900 тис./га, а на варіантах досліду з природною забур'яненістю цей період скоротився до 16 днів за норми висіву насіння сої 900 тис./га.

У 2008 році тривалість періоду «формування бобів - наливання насіння» у рослин сорту Устя без догляду за посівами та під час механічного способу догляду була на рівні 18 днів, а за збіль- 


\section{СТОРІНКА МОЛОДОГО ВЧЕНОГО}

шення норми висіву насіння до 900 тис./га скоротилась до 17 днів. Скорочення цього періоду до 16 днів ми спостерігали на варіантах досліду 3 хімічним способом догляду за посівами за норми висіву 600 і 700 тис./га, а за збільшення норми висіву до 800 і 900 тис./га тривалість цього періоду була 15 днів.

Рослини сорту Романтика в 2008 році період «формування бобів - наливання насіння» проходили за 18 днів за норми висіву насіння 600 тис./га не залежно від догляду за посівами. На варіантах без догляду цей період скорочувався під час збільшення норми висіву до 800 тис./га, в разі механічного догляду цей період скорочувався за збільшення норми висіву до 900 тис./га, у випадку хімічного способу догляду за посівами тривалість цього періоду скорочувалась вже за збільшення норми висіву до 700 тис./га на 1 день, а під час подальшого загущення посівів цей період ще скорочувався до 16 днів.

Погодні умови 2009 року на проходження періоду «формування бобів - наливання насіння» у рослин сорту Устя на варіантах без догляду не впливали і тривалість цього періоду була на рівні попередніх років. Під час механічного способу догляду за посівами тривалість цього періоду була 18 днів, а скорочувалась на 1 день за збільшення норми висіву насіння до 800 і 900 тис./га. На варіантах 3 хімічним способом догляду за посівами цей період тривав 17 днів і також ми спостерігали скорочення його тривалості за збільшення норми висіву насіння до 800 і 900 тис./га.

Тривалість періоду «формування бобів - наливання насіння» у рослин сорту Романтика за погодних умов 2009 року була 18 днів незалежно від догляду та норм висіву, скоротилась тривалість цього періоду під час механічного способу догляду за посівами 3 нормою висіву 900 тис./га та з нормою висіву 800 і 900 тис./га під час хімічного способу догляду за посівами.

Дозрівання рослин сорту Устя в 2007 році найдовше було на варіантах без догляду, але збільшення норми висіву насіння до 800 тис./га прискорило його дозрівання на 2 дні. Під час хімічного способу догляду за посівами період «наливання насіння - стиглість» тривав 17 днів, а скорочувався за збільшення норми висіву до 700 i 800 тис./га на 1 день та під час подальшого загущення посівів ще скорочувався цей період до 15 днів.

Найдовше в 2007 році дозрівали рослини сорту Романтика на варіантах без догляду, під час механічного способу догляду за посівами тривалість періоду «наливання насіння - стиглість» становила 20 днів, а скорочення цього періоду на
1 день ми спостерігали за збільшення норми висіву насіння до 900 тис./га, під час хімічного способу догляду за посівами цей період тривав 17-20 днів. Слід відмітити, що 3 кожним збільшенням норми висіву насіння на 100 тис./га скорочувалась тривалість періоду «наливання насіння - стиглість» на 1 день.

У 2008 році, у зв'язку з тим, що на період збирання врожаю спостерігалась більш суха погода ніж в 2007 та 2009 роках період «наливання насіння - стиглість» був найкоротшим і становив 17 днів у рослин сорту Устя, скорочувався він за збільшення норми висіву до 800 і 900 тис./га на варіантах 3 механічним та хімічним способом догляду за посівами. Рослини сорту Романтика в 2008 році дозрівали довше ніж рослини сорту Устя. Період «наливання насіння - стиглість» на ділянках без догляду тривав 20 днів, за збільшення норми висіву насіння до 800 і 900 тис./га він скоротився на 1 день. На варіантах досліду із механічним способом догляду за посівами тривалість цього періоду не змінювалась під час збільшення норм висіву насіння. За хімічного способу догляду за посівами тривалість дозрівання рослин скорочувалась зі збільшенням норми висіву насіння до 700 і 800 тис./га на 1 день та подальше загущення посівів ще скорочувало період дозрівання культури на 1 день.

В 2009 році тривалість періоду «наливання насіння - стиглість» була 17 днів у рослин сорту Устя, довшим на 1 день був цей період на варіантах без догляду 3 нормою висіву насіння 600 i 700 тис./га, а скорочення цього періоду до 16 днів ми спостерігали під час збільшення норми висіву насіння до 700 тис./га на варіантах 3 хімічним способом догляду за посівами. Рослини сорту Романтика в 2009 році в фазі повної стиглості можна було відмітити через 19 днів після настання фази наливання насіння, довшим на 1 день цей період був на варіантах без догляду та скорочення цього періоду до 18 днів можна було спостерігати під час збільшення норми висіву насіння до 800 і 900 тис./га на варіантах досліду з хімічним способом догляду за посівами.

Висновок. Тривалість вегетаційного періоду насамперед визначається властивостями досліджуваного сорту.

Найбільше на тривалість періоду вегетації та окремих фаз росту і розвитку рослин сої впливали погодні умови року.

На всіх варіантах досліду, спостерігалось значне скорочення вегетаційного періоду рослин сої в посушливий 2008 рік.

Спосіб догляду за посівами не істотно впливав на органогенез рослин сої. 
А загущеність агрофітоценозу позначилось на проходженні фаз росту і розвитку сортів Романтика та Устя.

\section{БІБЛІОГРАФІЯ}

1. Бабич А. О. Соя для здоров'я і життя на планеті Земля : [монографія] / А. О. Бабич. - К. : Аграрна наука, 1998. - 272 с.

2. Бахмат О. М. Моделювання адаптивної технології вирощування сої : [монографія] / О. М. Бахмат. - Камянець-Подільський : видавець Зволейко Д. Г., 2012. - 436 с.

3. Огуриов Є. М. Соя у Східному Лісостепу
Підвищенні норми висіву сприяли скороченню періодів «формування бобів» та «наливання насіння».

України : [монографія] / Є. М. Огурцов ; за ред. М. А. Бобро. - Х. : Харк. нац. аграр. ун-т, 2008. $270 \mathrm{c}$.

4. Шевніков М. Я. Наукові основи вирощування сої в умовах лівобережного Лісостепу України : [монографія] / М. Я. Шевніков. - Полтава, 2007. -208 c. 